\title{
Article
}

\section{Public participation on dam building in South Africa: a case study of the Berg Water Project}

\author{
Lisa Thompson \\ lisa.lit@iafrica.com
}

\begin{abstract}
This paper examines the participatory processes which led to the building of the Berg River Dam in South Africa's Western Cape province. The government-led formal participatory processes stand in contrast to the mobilisation of environmental activists against the building of the dam. In this case, the creation of formal participatory forums both subverted and neutralised resistance of the environmental movement and civil society against the building of the dam, largely through the mobilisation of policy discourses on water 'scarcity'.
\end{abstract}

\section{Introduction}

This paper examines participation in South African water and development debates in the context of global discourses on water and natural resource management. ${ }^{1}$ The recent developmental emphasis on local participation in natural resource management, particularly water, through global processes such as the World Commission on Dams (WCD) dialogue and report (2000) is analysed in relation to how water supply and demand strategies are framed at the national and local level in South Africa.

This paper seeks to examine these issues by focusing on participatory processes around water scarcity management in the Western Cape, contrasting in particular the formal participatory process led by government in relation to the local environmental movement's mobilisation efforts during the leading up to the building of the Berg Water Project (BWP), which includes the Berg River Dam² (hereafter referred to as the BWP). The degree to which communities, especially poorer, more marginalised groups, are able to exercise their citizenship in meaningful ways is thus 
examined in relation to what Kabeer (2005:23) describes as horizontal and vertical axes of participation. Horizontal (community based) spaces refer to those spaces created by citizens themselves (this includes forms of spontaneous social mobilisation as well as social movement activism). Vertical spaces include formal and/or institutionalised spaces for participation organised by government. The degree to which participation brings about change, or at least a discernible impact on policy, is taken as the measure of the degree to which participation is meaningful (see, for example, Cornwall and Coelho 2006). In this case study, policy discourses on water scarcity form a specific backdrop to forms of participation, as the policy discourse on water features a strong emphasis on the science of water scarcity management. In relation to this, debates on water as a scarce resource have featured prominently in global and national policy discourses. There is significant societal resistance to the types of 'scarcity control' policies advocated by many governments, as well as controversy about the construction of scarcity as a validation for many of these policies (Mehta 2005). The global environmental movement has been at the forefront of highlighting weaknesses and flaws in local and global constructions of water scarcity, thereby bringing the notion of water scarcity into the realm of public scrutiny, particularly in relation to building dams. The paper thus includes a brief discussion of the role of the environmental movement in the Berg Dam participatory process.

This paper aims to highlight the socioeconomic aspects of participation in discussions of governance of the environment and the management of scarce natural resources. While the paper focuses on the participatory dynamics involved in WRM, analytical and policy debates on water as a 'scarce' resource are also examined to contextualise the debates on water supply strategies.

\section{Water resource management in the Western Cape}

South Africa's current National Water Resource Management Policy Framework has been praised by many international organisations for its commitment to social justice. Since 1994, two new regulatory Acts came into force, the Water Services Act (WSA) of 1997 and the National Water Act (NWA) of 1998. The WSA laid the basis for the government's Free Basic Water (FBW) service programme which began in early 2001. This policy commitment is mediated by the highly politicised debate between the environmental movement and government on citizenship rights and the 
dominance of neoliberal economic ideology in water service delivery. This purported bias is said to favour the interests of big business and industry, wealthy farmers and urban elites rather than the poor with regard to water allocation, according to analysts such as Bond (2002a, 2002b), Mehta and Ntshona (2004), Mehta (2005, 2006).

Interviews for this case study in the City of Cape Town (CCT) and with officials in the Department of Water Affairs (DWAF), which focused on water supply and demand strategies, show that both bulk water supply and water service delivery (under the control of DWAF and the CCT) are viewed as technical management exercises. This obscures many of the trade-offs being made with regard to managing water as a socio-economic right on the one hand and as an economic good on the other, as Mehta and Ntshona (2004) and Mehta (2006) point out. As will become clear from the participatory process around the building of the BWP, there is also a tendency to construct notions of water scarcity in purely scientific terms, largely devoid of political or economic dimensions. In terms of participation, one of the offshoots of this approach to Water Resource Management (WRM) is that participants in formal processes must become proficient in the language of the scientific policy discourse on water scarcity and how to overcome it, in order to be taken seriously in public fora on water provision options. The scientific discourse in dam building has been subject to analytical scrutiny from both national and international perspectives, and it is to these critiques that we briefly turn before examining how local communities found themselves absorbed into the policy debates on water scarcity in the western Cape.

\section{Meanings and interpretations of water scarcity}

Du Plessis (2000), Turton (2000) and Ashton (2000) have discussed the nature of the policy debate on water scarcity in international, regional and national contexts respectively using constructivist (du Plessis) and neorealist (Turton and Ashton) analytical perspectives. They concur that the construction of 'scarcity' in policy discussions on water is not something to be accepted as a purely objective scientific enterprise. ${ }^{3}$ Turton (2000:41-55) argues that concepts developed by Homer-Dixon (1996) such as 'hydrocide' ${ }^{4}$ and what Ohlsson and Turton (1999) have referred to as 'water poverty' and 'structurally induced relative water abundance (SIRWA)' all allude to the link between first order resources (in this case water), and second order resources, that is the socio-political adaptive capacity of the state or states concerned in their responses to water 
management. The ways in which states manage competing demands to water, as well as how they resolve supply and demand issues are an integral part of what Ohlsson refers to as 'second order resources'. Turton (2000: 44) explains that it is the 'social adaptive capacity' of states (and communities) which enable them to overcome first order scarcity issues and to evolve to a point of 'relative (water) abundance'. States such as Israel show such adaptive capacity at the policy level with regard to water.

Approaching the debate on regional (transnational) and sub-national water scarcity from a critical theory perspective, Swatuk and Vale (2000) and Bond (2002a) point out that the debates on water scarcity coincide with the unequal allocation and distribution of resources. Scarcity in this context is understood primarily as in political, rather than in economic or scientific, terms and relates to what economic policies the state in question sees fit to adopt. 'Scarcity for whom?' the authors pose, noting that all citizens do not share equally in scarcity or abundance of natural resources. Relating this point to our case study of water resource management at the local level in South Africa, the South African government continues to emphasise the need for more water storage in South Africa as a way of overcoming scarcity, as is emphasised by the case study presented here. Bond (2002a) and Swatuk (2000) point out that water storage and transfer schemes have dominated the South (and southern) African landscape, with a clear bias towards industrialisation, for decades. The link between supply and demand side issues will be explored in greater depth particularly in relation to questions of public input and participation in subsequent sections of the paper.

The case study of the BWP is also illustrative of the pros and cons of public participation in natural resource management policy processes as well as the ways in which lay knowledge and scientific knowledge intersect and mediate one another. In the context of water management, the construction of the 'fact' of water scarcity illustrates how public knowledge and input are mediated by the release of information on the part of government. Participation in the processes which legitimised the building of the dam show the degree to which some level of 'expertification' is necessary to enter such debates and to be able to participate in meaningful ways. The case study emphasises the democratisation of participation, and the creation of formal participatory spaces can lead to the watering down of the force of organised resistance to the point that it becomes ineffective.

The lead up to the building of the Berg Dam involved a drawn out 
government-driven participatory process aimed at including all 'interested and affected parties', to debate the various options for solving the Western Cape's water 'crisis'. As part of this, in the early 1990s scientific assessments undertaken by engineering consultants on behalf of government resulted in a document called the Western Cape Systems Analysis (WCSA). This document formed the basis of a series of public meetings which led to the public approval of the dam. Parallel to this process, a mandatory Environmental Impact Assessment (EIA) on the BWP was undertaken and released for public comment. Finally, civic input to the process of building the dam was institutionalised through the setting up of the Environmental Management (now Monitoring) Committee (EMC). While the dam's construction did not raise the sort of displacement of livelihoods issues which have assured the publicity and level of environmental movement activity associated with mega-dams such as the Lesotho Highlands Water scheme, and the Sardar Sarovar in India, the ways in which government drew all stakeholders, including environmental groups, into public processes related to the actual building of the dam is indicative of the ways in which vertical spaces of participation may 'water down' more spontaneous (social movement) forms of activism. In the case of the BWP, activism against the building of the BWP took place after the public participatory process, and largely on the mobilisation impetus derived from the World Commission on Dams final report. The Western Cape government was able to point to public participatory processes in response to this mobilisation, effectively claiming that the building of the dam had achieved broad public consensus. As will be pointed out, this process of public participation was deeply flawed, but still served to remove the impetus from the environmental movement's subsequent mobilisation strategies.

\section{Social movements (SMs) and theoretical perspectives on science, citizenship, environment and water}

Critical development approaches taken by Escobar (1995), Crush (1995) and others emphasise the degree to which social movements (SMs) challenge prevailing local and global hegemonic discourses on the 'science of development'. How SMs also influence international norms and values, especially as these relate to the notion of global social justice, is also viewed as critically important. Stienstra's (1999) more critical perspective on SMs emphasises how they also mediate between state and society and can 
perform a regulatory, state legitimising function. Robert Cox's (1987) influential work Production, Power and World Order explores the interplay between social forces and social movements in maintaining or challenging the international status quo, as well as the spaces in which distinctive alliances of social forces can lead to changes to global knowledge and structures.

Questions of representation arise here and are linked to the controversy about the extent to which NGOs - local, national and international represent social movements as well as how collective identities and social movements coalesce. Stavenhagen (1997:33) makes a distinction between what he calls 'truly non-governmental popular organisations' and NGOs which are 'but surrogates of government aid agencies'. The former are characterised by, amongst other things, 'the articulation of the demands of the underdog', and are often 'at odds with their own governments and challenge existing paradigms of governance', as well as 'frequently seek to attain objectives which would entail alternative forms of economic development, political control and social organisation'. However, the risk of cooption is ever present (O’Brien et al 2000:20).

The strength of global social movements (GSMs) is said to be their 'global vision' and their major role, 'the way in which they might contribute to increasing democracy by creating a global civil society’ (O’Brien et al 2000: 22). However, GSMs are also subject to cooption into formal structures which can change as well as neutralise resistance.

The prolific work of Patrick Bond focuses on GSMs' and SMs' ability to challenge hegemonic knowledge at both local and global levels, for example, in South Africa the way that the environmental movement draws on global anti-commodification and anti-capitalist discourses to challenge the IMF/ World Bank approach to development in general, and water resource management in particular, as these emphasise the commodification of water and view natural resource management as a 'technicist' science. The degree to which the South African environmental movement is seen as representative of grassroots environmental concerns, including brown environmental issues, has been a contentious issue as environmentalism, especially the green variety, ${ }^{5}$ has been branded by some policy-makers in government as a bourgeois form of activism. This is not in fact the case in South Africa, as this case study highlights. Dam building resistance has tended to remain the preserve of the organised environmental movement as a 'green' environmental issue, but there has been collaboration with trade unions, and 
joint declarations on related 'brown' environmental issues relating to dam building such as higher water tariffs - which the BWP case highlights well. However, the environmental movement's resistance to the BWP only gained momentum after the formal government-led participation process had taken place, effectively delegitimising their concerns.

The extent to which horizontal and vertical forms of participation interface in meaningful ways is an area of enquiry which requires careful scrutiny, both in terms of broader social movements, as well as community action in relation to public participatory processes. In relation to the building of the BWP, two community groupings took part in formal participatory fora after the dam had been approved. The Franschhoek Community Alliance and the West Coast User Group (WCUG), challenged government not in terms of the need for the dam, but on socio-economic, rights based claims in the case of the Franschhoek Community, and on environmental impact concerns in relation to the WCUG. The Franschhoek community, ${ }^{6}$ as the most affected community because of the proximity of the dam to the town of Franschhoek, campaigned for a different interpretation of environmental and socio-economic justice for poorer communities in the Franschhoek area. The troubled history of the Franschhoek First strategy has comprised the single biggest challenge to the existence of the EMC, as discussed in second half of this paper.

The successes and failures of mobilisation and participation show both the promises and shortcomings of the concept of environmental justice in relation to scientific 'developmental' claims to water management, particularly in relation to neo-liberal economic policies. Brian Wynne’s (1996) exploration of how lay people challenge scientific expertise refers mostly to a 'developed' state context. Wynne discusses the ability of less educated, or less 'policyconversant' groups to challenge these discourses on their own terms and in relation to their own locally based knowledge of resource management. The degree to which scientific development is critiqued through processes of community participation in the southern African, and in this case South African, context seems to be significantly less than what has been described by Wynne and others in more developed state contexts, especially when focusing on poorer urbanised groups. Nonetheless, community resistance did emerge in relation the building of the Berg River Dam. However, this case study illustrates the power of the scientific developmental policy frame on water scarcity in both vertical and horizontal participatory processes.

Before turning to the BWP case study, a brief discussion of linkages 
between global and local environmental concerns with regard to water takes place in the next section.

\section{The South African national environmental movement and South Africa's neoliberal economic policies in environmental perspective}

Environmental mobilisation on the issue of water has occurred in relation to rights, and in the case of South Africa, this is constitutionally enshrined and backed up by legislation on FBW. Bond (2002a) and others have focused on how these rights are mediated through water resource management being captured in government policy as an economic process. This economic focus is then fitted into broader governance and developmental frames (such as New Partnership for Africa's Development, NEPAD) where the emphasis is on allowing the forces of the (free) market to ensure economic growth, and cost-effective delivery of services, including water. At the governmental level, South Africa has attempted to reconcile these two departure points, arguing that they are not mutually incompatible. In fact, as an offshoot of the Bonn Recommendations for Action (2001) following the International Conference on Freshwater held in 2001, the Declaration of the African Ministers (2001) makes this commitment explicit (and shows South Africa's African influence at international fora at the same time). The declaration reads: 'We are determined that our governments, nongovernmental organisations, civil society and the private sector extend full support to the implementation goals of the NEPAD' (Declaration of the African Ministers 2001).

The environmental movement has been instrumental in highlighting the tensions between environmental justice approaches to water service delivery and the neoliberal developmental emphasis on cost recovery. Important in this regard are the roles of formal and informal groups linked to SANGOCO (South African NGO Coalition), as well as those linked to or taking their cue from the Social Movements Indaba, organised around the time of the WSSD in Johannesburg (Bond 2002a). In the Cape region, the most influential of these groupings have been the Environmental Monitoring Group (EMG) and the Wildlife and Environmental Society of Southern Africa (WESSA) as well as, to a lesser extent, the local branch of Earthlife and the South African Municipal Workers Union (SAMWU).

In South Africa, government water resource management strategies which have attempted to reconcile rights based and economic goods based approaches to water have had different impacts, depending on the translation 
of specific policies into practice. The FBW policy is a good example of this. According to Liane Greeff of the EMG, the FBW policy is being interpreted differently and applied differently in various parts of the country. In general, cost recovery and cut-off structures are in conflict with FBW. According to Greeff, it seems that 'the technocrats are not working sufficiently with communities to find solutions’ (Greeff, EMG, Interview July 16, 2004) (see also Bond 2002a).

The importance of water as both an economic good as well as a fundamental right has been made much more visible in the South African context through the government's direct involvement in the WCD process. Kader Asmal, a commissioner to the WCD and one of the influential government forces behind the Cape Town based WCD secretariat, played an instrumental role in creating a hitherto unprecedented platform for interaction on water resource management between environmental NGOs, CSOs, civil society groupings, international environmental groups (such as the International Rivers Network) and government. A multi-stakeholder symposium to allow for interaction, debate and deliberation on the WCD process was also held in South Africa in July 2001. Parallel to this process, as well as arising from it, was the creation of national, regional and international networking structures. ${ }^{7}$

Resistance to dam building at both local and national level has been increasingly sustained by these networks, as well as by the WCD process. In terms of mobilising broader grassroots resistance, the environmental movement's strategic alliance with disadvantaged groups has tended to coalesce more on issues of service delivery and the economic impact of water resource management, the brown environmental issues referred to earlier, than on what are perceived as essentially green environmental issues (Bond 2002a, 2002b, MacDonald 2002).

The WCSA process initiated by government and the BWP Environmental Impact Assessment, which culminated in the setting up of the EMC, initially removed the impetus from the environmental movement's resistance with regard to protesting about the dam and its potential socio-economic impact. The very clear support of the disadvantaged communities of Franschhoek, Paarl and Wellington for the building of the dam in terms of job creation made mobilisation against it somewhat difficult in terms of social justice concerns, especially in terms of WCD criteria (which state explicitly that affected parties compliance is critical). In addition, Greeff of the EMG (Interview July $16,2004)$ points out that most of the local NGOs and CBOs which involved 
in channelling and organising resistance to dam building were asked to participate in the WCSA process. Greeff states further that 'a lot of energy went into opposing the Lesotho Highlands water project... (t)here are just so many issues and people just don't have a lot of time to get on top of all the different dams' (Greeff, EMG, Interview July 16, 2004). The extent to which environmental NGOs as representatives of SMs become involved in policy debates is also largely contingent on funding and staff - and of course sufficient grassroots resistance. O’Brien (2000:12) points out that social movements 'rely on mass mobilisation because they do not directly control levers of power such as the state'. Where such mass mobilisation is not present, in either its local, national or global form, the impetus which environmental NGOs can bring to bear appears minimalised. In the case of the BWP, the dam was motivated by government as necessary to alleviate the imminent crisis of water scarcity facing the Western Cape. This helped to validate the formal (vertical) processes of participation and to undermine other (horizontal) forms of resistance.

\section{The participation process on water scarcity in the Western Cape}

In spite of the lack of an official Water Demand Strategy in 1989, the then provincial government proposed the building of another large dam in the Western Cape, arguing that another dam was necessary to ensure sufficient storage for summer months. The Western Cape already has a number of large dams, which supply the CCT and outlying towns. The largest and most important of these is the Theewaterskloof dam in the Villiersdorp area, which is part of a larger inter-basin transfer scheme which includes the Berg River, Voëlvlei in the Breede River area, Wemmershoek dam in Franschhoek, and the Steenbras upper and lower dam in the Helderberg/ Gordons Bay area. All of these dams are considered large dams by international standards, and there are a number of smaller dams and diversion schemes as well. 'Supply assurance' for industrial growth and domestic consumption has been the chief rationale on the part of government for building another dam in the Western Cape. This rationale continued throughout the Democratic Alliance (DA) era of the late 1990s in the Western Cape (where the DA and the National Party - NP dominated in provincial legislature, effectively controlling the province) and is still prevalent among the current provincial and local government structures dealing with water (Dowling, WESSA, Interview June 8, 2004).

The initial building of the BWP was proposed in the late 1980s, when 
dam building was not yet contested in South Africa. As one local government interviewee put it, 'in those days it used to be a simple process, we decided we wanted a dam and then we went ahead and built it'. However the dam's official approval process ran into the democratisation of local governance processes which began in the mid 1990s. Early pressure from local environmental groups on the proposed building of the dam led to the Western Cape Systems Analysis (WCSA) Evaluation Process that took place between 1995-1996 (Ninham Shand 1996:4).

The WCSA/EIA process mentioned earlier should be seen in the context of how formal participatory spaces were managed by both provincial and local government structures. DWAF at provincial level, and the City of Cape Town at the local government level, proposed a set of options to a group of selected 'interested and affected parties' in a series of publicly advertised meetings. These options were packaged and presented by the consulting engineering firm favoured by DWAF in the Western Cape (Ninham Shand), and the participation process was contracted out to a conflict management and participation consultancy (Zille Shandler and Associates). Participants were posed with an array of options. The most feasible, according to various scientific academic reports attached to official documentation, was the Berg River dam - if the Western Cape's water scarcity problem was to be addressed in the medium term. The entire WCSA participatory process then ran parallel to the development of the BWP EIA, which is mandatory in terms of environmental legislation. ${ }^{8}$ The government rationale for the parallel processes was that the water crisis in the Cape region was so acute that the EIA process could not be put on hold, as it might jeopardise the water security of the region if the building of the dam was delayed in any way (Fourie, Interview December 12, 2003; Dowling, Interview June 8, 2004). As a result, many participants who were involved in the WCSA were under the impression that they were involved in a 'post-hoc' process - as EIAs are not usually commissioned before public consensus is reached. A few excerpts from the minutes of meetings, as well as some of the (many) comments from participants, emphasise how ineffective government/consultancy tactics were in addressing public concerns:

... (a participant) raised a concern that the Skuifraam Scheme was perceived to be a fait accompli and that the decision to build the dam had already been taken. (WCSA Public Meeting, Paarl, December 4, 1995)

It was suggested that the WCSA evaluation was a whitewash. (WCSA Public Meeting, Grabouw, February 13, 1996) 
It was argued that engineers were promoting the building of dams because they had a vested interest in building them. (WCSA Public Meeting, Villiersdorp, March 26, 1996)

Concern was expressed that the Skuifraam Dam IEM process and the Western Cape Systems Analysis evaluation are running at the same time and that participants do not have the capacity to make a meaningful input into both processes. (Skuifraam Dam Integrated Environmental Management Process, Workshop, Franschhoek, June 13, 1996)

As a result of these concerns, a Task Team was elected by participants to the WCSA process to deliberate the supply and demand side options set out in the WCSA documentation. A series of independent reports were commissioned from scientists, and economists and a social impact study was also done (WCSA Evaluation Report, Ninham Shand and DWAF 1997). Based on the scientific reports, the Task Team then ranked the supply and demand side options provided by DWAF and gave the go ahead for the building of the BWP dam, providing the EIA process raised no strong environmental concerns. Interviewees involved in the process have conveyed that there really was no other choice to the BWP in terms of the ranking of options (see endnote 13) (Fourie, Interview December 12, 2003; Dowling, Interview June 8, 2004, WCSA, 1997).

The final EIA document, also commissioned by DWAF from Ninham Shand, was publicly aired in 1996 and calls for comment were made. By the end of 1997 this process had been finalised, save one of the final conditions for the building of the dam made by the then Minister of Water Affairs Kader Asmal - that the CCT show its commitment to Water Demand Management through the drafting and implementation of an effective water demand management strategy.

It was only from early 1999 - over a year after the formal participation processes were wound up - that there were further objections to the building of Berg River Dam from local and national environmental groups. As mentioned, this opposition flared largely as a result of the development of the formal WCD guidelines on environmentally sustainable dam building. The environmental NGOs opposed the dam in terms of three factors: the lack of demand management on the part of the CCT, the increase in cost to Cape Town's water supply, and environmental impacts to the whole of the Berg River system (EMG Letter to Department of Environment and Tourism (DEAT) and DWAF July 29, 1999). SAMWU was opposed to the building of the dam more purely in terms of its effects on water tariffs for the poor. 
According to SAMWU,

[i]t is SAMWUs position that there will be a drastic increase in water tariffs as a direct result of this project that will hit the poor of Cape Town, who are battling to pay for water. (SAMWU Press Statement, July 29, 1999)

Some of the points made by the EMG's submission to DEAT and DWAF were again reiterated in a letter to the new Minister of Water Affairs, Ronnie Kasrils, in February 2001. At this stage EMG drew on its considerable involvement in the WCD process to argue that the BWP needed to be more thoroughly debated before being implemented, and that a multi-stakeholder workshop should be held to illustrate that if, against the background of the WCD, 'the dam is indeed the last resort and is the best option'(Greeff, July 2004; EMG letter to DWAF, February 2, 2001). Economic viability in the light of other options was also highlighted. Kasrils' reply dismissed any further deliberations on the dam, stating

[...](a)s regards the (BWP) dam I would like to reiterate what I have said at the recent WCD Forum meeting. The processes which have been followed up until this point had been thorough and closely conformed to all prescripts of existing rules and regulations. We have examined the processes followed against the WCD guidelines and found there to be good compliance ... I trust that you will understand my position on this issue and that I have to take into regard that delays in the construction of (BWP) Dam will cause the risk of severe water shortages to the Cape Metropole to be simply too high. (DWAF 2001, Kasrils, Letter to EMG, May 8, 2001)

The role of scientific consultancies in mediating the socio-economic aspects of WRM cannot be underestimated. For example, in response to criticism of BWP as out of line with the WCD, Ninham Shand's Environmental Division together with DWAF, prepared a review paper detailing the WCD guidelines applicability to the BWP for the WCD Symposium held in Gauteng in July 2001. The document makes for interesting reading, as it outlines the degree to which WCD guidelines are 'relevant' to the building of the dam. The authors of the paper, Luger and Van Niekerk of Ninham Shand, state

[t]he review concluded that the environmental and public participation processes undertaken for the (BWP) dam broadly complied with the WCD guidelines. However it became clear that certain of the guidelines were either only marginally applicable or inapplicable to the BWP dam. (2001:1) 
As the discussion on the EMC below highlights, this dismissal of the WCD guidelines amounts to a denial on the part of the WCSA and EIA consultants of the potential effects of the building of the dam on the ecology of the West Coast, as well as its related socio-economic impact - two issues which are stressed as very important in WCD guidelines.

\section{The cost of the BWP: implications for social justice?}

The socio economic impact of the dam has not received much attention in the media, in spite of the fact that according to City of Cape Town officials themselves, the WCSA participation process did not fully consider demandside and recycling alternatives. As a chief official in Reticulation Services in the CCT states,

The (WSDP-figure of the) amount of water recycling of between 6-15 per cent is a thumbsuck. It depends on the season and is sometimes more than that, but in 6 months we may have a better sense [...] We believe that a very big part of the potential yield of Skuifraam, that is now costing one point something billion rand, could be achieved much cheaper by recycling and replacing treated effluent for irrigation instead of potable water. (Interview May 20, 2004)

The WDM strategy was developed in the mid 1990s to show DWAF that the Berg River Dam was really needed, as DWAF will not underwrite new dam schemes in the absence of visible WDM strategies (Dowling, Interview June 8, 2004). The Integrated Water Resources Plan (IWRP) identified three 'supply and demand' packages which are seen as complementary to the BWP, and are supposed to help bring down water demand, as well as cater for water demands which, according to growth projections, will exceed supply of even the Berg dam by $2010 / 2 .{ }^{9}$ Recycling of water is mentioned briefly in the WSDP (pages 47-8) stating that it is a priority and that 'the CCT has appointed consultants to refine the work carried out in the IWRP study' (City of Cape Town 2001:48).

Ironically, the dam will only be completed in 2007, and in the intervening years the Cape Province has managed on available water, although the severe 2004/5 drought brought about severe water restrictions. This does throw some doubt as to the urgency for the dam as stressed by government. It also highlights the linkage between the socio-economic dimensions of water management, and the science of water supply management as discussed at the beginning of this paper. Interestingly, the 2005 water shortage was blamed on the environmental movement as having delayed the building of 
the dam, although the movement's belated resistance had virtually no impact on its start and completion date (Argus, January 6, 2005).

According to the CCT's figures, the average increase of water tariffs for the next five years will be around 10 per cent per year, almost doubling the cost of water in the next ten years. ${ }^{10}$ This 'step up, step down tariffing' to the building of the dam is said to involve the least risk to the CCT and the TCTA, and will mean that future supply schemes can be implemented towards the end of the decade (CCT Bulk Water Supply Division 2004; Killick, CCT, Interview June 15, 2004). The full impact of the dam on tariffs will only be felt towards the end of the building, as it is then when the unforeseen costs will have a knock-on effect of the full amount owing.

There has been little resistance to these price estimates by either affluent or poorer ratepayers. This seems less as a result of apathy than lack of knowledge, combined with the CCT's ongoing insistence as to how water scarce the Western Cape has become. Information on the cost implications of the dam to the public has been sorely lacking, and the environmental movements have not been very successful in obtaining figures from government. As Laine Greeff (Interview July 16) of the EMG and Patrick Dowling (Interview June 8, 2004) of WESSA have pointed out, the motivation of groups like SAMWU to mobilise has usually been linked to the effect which water resource management has on poorer communities. The CCT and DWAF have reason to be hesitant to divulge the full financial implications of the dam on tariffs.

To summarise thus far, in the broader Western Cape context, the building of the Berg River Dam has elicited the rise of three kinds of community participation. The first of these is the process of formal (or vertical) participation which took place through the WCSA and EIA processes. The second form of participation has taken place through the resistance which arose around the WCD process mainly from the environmental movement. The third kind of participation resulted out of specific issues which have concerned smaller community groupings, such as the Franschhoek Community and the West Coast User Group (WCUG) mentioned in earlier. These latter forms of organisation can loosely be described vertical forms of participation as defined by Kabeer (2005). The initial activism around the concerns of these two groups has fed into the Environmental Monitoring Group (EMC) participatory processes, thus providing a case study of how horizontal and vertical forms of participation articulate. It is to the EMC participatory process that we now turn. 


\section{The Environmental Monitoring Committee (EMC)}

The institutional concept of an EMC comes from the National Environmental Management Act, NEMA, Act 107 of 1998, which makes provision for EMCs as public participatory spaces to oversee ecological or developmentally sensitive environmental policy processes (see DEAT 2005). The logic behind EMCs is that while they are in fact created by government, they are to be fundamentally non-governmental in their representation of all 'Interested and Affected Parties', interests in sustainable development processes. Environmental Monitoring Committees are to be set up (where deemed appropriate by the Department of Environment, Agriculture and Tourism, hereafter referred to as DEAT) through the Record of Decision (ROD) process following an Environmental Impact Assessment (EIA). The latter is in itself a formally constituted participatory process which will also be discussed briefly here. EMCs fall into that strange category of public representation as a result - a government organised non-governmental organisation (GONGO) - in that most of the representatives which constitute it are from civil society groupings, including the Chair. There are of course government representatives as well, but they are ostensibly there to assist in the role of public monitoring - at least in theory.

The Berg Dam EMC is the first of its kind to be constituted since NEMA came into effect, and its creation, evolution and current state of institutional torpor are useful indicators of the potentialities and limits of this type of government organised space. ${ }^{11}$ The circumstances leading up the establishment of the EMC are not particularly unusual to environmental debates, especially those around dam building, and thus the problems that have beset this EMC are likely to arise again in the future.

The EMC was set up in 2003, and consists of stakeholders who will be affected by the dam, ie upstream and downstream users (but notably not broad based urban groups). According to the Record of Decision (ROD) which came into effect once the EIA process had been through governmental channels, the Environmental Management Committee should be set in place by government to ensure ongoing participation of interested and affected parties. Ratepayers, previously disadvantaged groups, farmers, businesspeople and those involved in Franschhoek's tourist trade are represented, as well as the CCT, local and provincial government, and DWAF. Interestingly, while Paarl, Wellington, Villiersdorp and Franschhoek are represented in terms of civil society groupings, the Cape Town 
metropolitan area is represented only through environmental groups, and there are no urban user associations on the EMC despite the cost and environmental implications for urban water users. Thus while the dam is mostly being constructed for urban water usage, the EMC represents only peri-urban and 'rural' civil society. The degree to which this has been a strategy to legitimate the acceptance of the dam has been debated within and outside the EMC. Certainly the perception of cooptation seems to be an issue, and one which has raised its head throughout the EMCs troubled existence.

Three major issues have bedevilled the EMC since its inception. These are the issues of water quality and the salination effects of the dam on the lower Berg River; the issue of indemnity of committee members, and socioeconomic issues around livelihoods and the environment (Venter, EMC Chair, Interview May 8, 2004).

Debates around water quality are led by Dr Martin Fourie (a retired engineer) of West Coast User Group (WCUG) who has the scientific knowledge to be able to challenge DWAF and Ninham Shand's projections of the effects of the dam on the Berg River estuary. According to Fourie, the issue of water quality was not addressed by the original EIA and the impact of higher salination levels on the Berg estuary will be severe, causing both ecological damage and also affecting downstream industries as well as potential industrial development (Fourie, WCUG, Interview December 12, 2003; June 4, 2004). Fourie was also instrumental in mobilising the West Coast community on the issue of salination, and in ensuring that the WCUG got representation on the EMC. Initially, the West Coast was 'accidentally' left out of the process of public consultation on the EIA process, as well as the setting up of the EMC.

It is clear that the issue of downstream water quality cannot be ignored. However it is an especially difficult debate to enter into for the layperson. Flow weighted averages which are used to determine water quality in rivers are worked out using scientific calculations and different forms of modelling which are to the lay person quite impenetrable. ${ }^{12}$ Fourie has the support of environmental groups, but has been unable to exact any clear commitment to the problem he has highlighted within the EMC. Indeed, he is seen as something of a figure of fun by engineers at Ninham Shand who claim his data is unscientific. As Gorgens (Chief Engineer at Ninham Shand) put it in a personal interview,

... (his) approach is not totally scientific, although it has a fair degree of 
science in it. Right from the start I used to appreciate Martin's role because he was 'pushing the boundaries' and he was basically doing what all of us should be doing which is go out there and fight for our rights as we see them, even if we may see them wrongly. I am not saying what he is saying is not right. But his data is suspect (Gorgens, Ninham Shand, Interview June 1, 2004).

Government (and Ninham Shand) have argued that the EMC is not the 'right place' (or space) to be bringing up the problem of salinity effects on downstream users. This should be done through the Catchment Councils (which have yet to be set up in this catchment area as well as nationally), or through the EIA process which ran its course in the late 1990s. Paradoxically then, this particular environmental impact is seen as 'beyond the mandate of the committee'. This has raised real concerns as to the real power of the committee as a civil society 'watchdog'.

Thus, the EMC set up to monitor the building of the dam and to ensure civil society input to the process, has not been given powers of intervention should the dam building process raise serious environmental problems. This has led to another issue of contention - that of indemnity of those who sit on the Committee, especially those wealthy Franschhoek entrepreneurs who have lent their weight to the Franschhoek community representation on the EMC.

As Venter (EMC Chair, Interview May 22, 2005) points out, the EMC cannot halt the building of the dam, even though the committee is seen as responsible for addressing civil society issues. Instead, the EMC has to report to the Trans Caledon Transport Authority (TCTA), which is the government company appointed to oversee the building of the dam (and which incidentally, also oversaw the building of the highly controversial Lesotho Highlands Water Project). The TCTA in turn reports to DWAF. Fears of members within the EMC are that problems could then potentially spill over into potential liability cases. Ironically then, civil society representatives rather than government may be held responsible by affected communities. The TCTA and DEAT finally responded to this matter through the release of a publication on EMCs. The report argues that EMCs cannot be held liable, as 'the EMC is not one of the more common forms of legal entity ... (t)he EMC does not have a separate legal entity and so could not be sued in its own name as a juristic person' (DEAT 2005: 13). However, many EMC members remain unconvinced of this argument (Venter, EMC Chair, Interview May 22, 2005). 
The question of the mandate and power of the EMC also came to a head over its name. Members of the committee argued that since the ROD referred to a 'management' committee, by rights more power over the process of dam-building should be accorded. Government responded by changing the name of the committee from 'management' to 'monitoring'. While members have felt cheated by this sleight of hand, the issue of indemnity has been the channel through which the sense of powerlessness has been turned around and reflected back on government. The EMC has consistently drawn into question the degree to which government has given it a mandate to play a useful monitoring role over the building of the dam, and the EMCs focus on questions such as indemnity (to the great discomfort of the TCTA and other government representatives) show a lay understanding of the ways in which government can use formally created spaces of participation as a way of trying to control possible civil society resistance or dissatisfaction with policy decisions. The indemnity issue had not been resolved as of 2006 (Venter, EMC Chair, Interview August 17, 2006).

The third participation and legitimacy issue within the EMC is in relation to its monitoring of the empowerment initiatives which the dam contractors are beholden to under the auspices of the TCTA. At an EMC meeting held on June 10, 2004, the agenda was turned aside due to the inputs of the Franschhoek community. Just two weeks earlier the new TCTA appointed contractor had already sub-contracted to a company in Paarl to do the stone crushing and bush clearing required before the dam construction could begin, immediately undermining the affirmative action commitment in the eyes of the majority of local residents.

Subsequent efforts on the part of the EMC Chair to bring the Franschhoek community back into the EMC have failed, largely as a result of the fact that the TCTA representatives refused to apologise for the conduct of the TCTA as state owned company in charge of overseeing the Franschhoek First policy (Venter, EMC Chair, Interview May 22, 2005; August 17, 2006).

Largely as a result of the ensuing impasse between the Franschhoek Community and government, in 2005 both DEAT and DWAF officials claimed that the EMC had become 'dysfunctional' and should be replaced by public meetings as a more 'functional' form of public involvement.

However, remaining EMC committee members - most notably those representing stakeholder interests downstream of the dam, insisted that the EMC still had a role to play. Backed by legal counsel, members of the Committee declared that it would be against the EMC's ROD to be 
disbanded, and an interdict was brought against DEAT to this effect. After several stand off meetings between the Chairperson, DEAT and the TCTA, it was finally agreed that the EMC would continue to function, once 'conduct guidelines' were laid down. The EMC's role has been reduced to keeping track of what are known as 'sustainable utilisation processes' (SUPs) and monitoring environmental activities related to the dam in terms of the Environmental Management Plan (Venter, EMC Chair, Interview August 17, 2006).

Venter, as Chair of the Committee and head of the EMC Secretariat, states, '...the EMC was fine as long as it was a yaysayer...but as soon as it started to criticise (government) it was a problem. Why is government so worried about criticism?' (Venter, EMC Chair, Interview August 17, 2006). Members have called the committee a 'toothless tiger', but those who are ostensibly still committed to its monitoring role have remained within its ranks. Ironically, it has fallen to the remaining members to monitor the social responsibility dimension of the dam's construction (the Franschhoek First policy) as well, as the Franschhoek Community no longer participates.

\section{Conclusion}

As the WCD, WCSA and EMC participatory process make clear, at international/national; national/provincial and provincial/local levels respectively, the local and the global are interconnected by the scientific discourse on scarcity in relation to water resource management and development. This discourse tends to privilege understandings of water as an economic good, to be managed through scientific development strategies. The political economy of water - which takes into account the social, environmental and political (as well as economic) aspects of water seems ambivalently translated into current WRM policy strategies in the western Cape.

There is also a tension - and a complex set of power relations - underlying the science of managing scarce resources which is juxtaposed in many ways to the language of rights and empowerment of actors, in particular disadvantaged groups.

The case study also shows how the technological nature of the water management discourse also alienates those who are less educated and less well informed in the South. As is clear from the WCSA and the EIA processes as well as larger national and international processes such as those around the WCD, the really poor and uneducated are unlikely to be 
able to challenge the science which underpins these processes, even if they do participate. This does not necessarily translate into general passivity however - the Franschhoek Community's and WCUG's stance on the BWP dam building process shows that participatory fora can still be used in ways which allow for community mobilisation - although the outcomes of challenges in such public spaces may be less than satisfactory to the less powerful participants.

Anti-globalisation, anti-commoditisation movements on the environment, natural resource management, and on dam building, have been much more vociferous at the national level in the South African context (Bond 2002b, Greeff, Interview July 16, 2004). While these debates are certainly at least indirectly relevant to supply side biases in broader water resource development strategies such as that of the Western Cape provincial government, this case study indicates there may be insufficient synergy between local and national activists' networks leading to the kind of social movement activism found on dam building in India for example (Mehta 2005).

The BWP case highlights the different layers of policy discourse on green and brown environmental issues, and the ways in which these are dealt with in developmental terms at the local level, as well as the challenges and potential pitfalls of participation for civil society, either through formal (vertical) participatory spaces or through social mobilisation (horizontal participation) in relation to water resource management and development discourses.

\section{Notes}

1. These themes build on research on the theme of Citizenship and Science in the Global Context in the Development Research Centre on Citizenship, Participation and Accountability, funded by DFID and hosted by the Institute of Development Studies at the University of Sussex. A different version of this paper was published as Thompson, L (2005) 'Managing mobilisation: participatory processes and dam building in South Africa, the case of the Berg River Project', Working Paper 254 by the IDS.

2. The dam was originally called 'Skuifraam' after the name of the largest farm on which the dam would be built. The Project consists of the dam as well as a supplement scheme.

3. While Turton (2000) does emphasise the political aspect of managing water scarcity, his analysis places emphasis on the state. Swatuk and Vale (2000) and Thompson (2002) argue that this obscures the role of local communities in determining water resource allocation priorities. 
4. Hydrocide refers specifically to a state's inability (or unwillingness) to use its water resources in an environmentally sustainable way - waste water returned to rivers untreated is one example with regional implications.

5. McDonald (2000:13) makes the distinction between brown and green environmental concerns, the former referring to issues of water, sanitation and sewerage as well as basic infrastructure such as roads and drains that are so lacking in many urban townships.

6. Franschhoek is situated a short distance from the Cape Town Metropolitan Area (CMA).

7. The South African Water Caucus (SAWC) is one example. In 2001 the EMG cohosted the WCD multi-stakeholder symposium together with DWAF, the National Committee on Large Dams and the World Conservation Union (IUCN)

8. EIA processes were tightened up even further by revisions made in 1997 to the Environmental Conservation Act of 1989.

9. In detail, Package 1 targets low income areas (it includes pressure management initiatives, user education, eliminating automatic flush urinals, repairing leaks and tariffs, metering and credit control). Package 2 targets businesses and large consumers, and includes promoting boreholes; introducing water efficient fittings and promoting grey water reuse. Package 3 once again looks at supply side strategies - highlighting for example the Voëlvlei Augmentation scheme; the use of the Table Mountain aquifer near Franschhoek; diverting water from the Lourens River in Somerset West; using treated wastewater for irrigation, and right down on the list, 'treated wastewater reclaimed to potable standard'. The last on the list is desalinating sea water, preceded by the idea of towing icebergs to the Cape (City of Cape Town 2001: 43).

10. Assuming a low inflation rate of 6.5 per cent the average water tariff is set to rise by 10 per cent between 2003/4 and 2006/7 - or 50 per cent in five years, and thereafter at between 5 and 9 per cent (Killick, Interview June 15, 2004).

11. While other examples of EMCs are discussed in the document released by DEAT (2005) the BWP EMC oversees the only environmental project run entirely by government.

12. In simple terms, the debate arises as to how often the average of salinity levels is checked as this can vary greatly depending on offtake and seasonal rains. Fourie's argument is that the original EIA has used projected averages that do not take sufficient account of this variability in the Berg. As a result, Fourie is of the view that the grave salinity problems that the West Coast will face are not to be found in Ninham Shand's EIA report. If Fourie's reading of the situation is correct, given the fragile eco-system and development status of the West Coast, the long term potential environmental consequences could be very serious indeed. 


\section{References}

Ashton, P (2000) 'Southern African water conflicts: are they inevitable or preventable?', Africa Dialogue, Monograph Series No 2. Pretoria: African Water Issues Research Unit, University of Pretoria.

Arrighi, G, TK Hopkins and I Wallerstein (1989) Anti-systemic Movements. London: Verso.

Bond, P (2002a) Unsustainable South Africa: environment, development and social protest. London: Merlin Press.

Bond, P (ed) (2002b) Fanon's Warning: a civil society reader on the New Partnership for Africa's Development. New Jersey: Africa World Press.

Bonn Recommendations for Action (2001) Bonn International Conference on Freshwater, Bonn, Germany, December 3-7.

Cornwall, A and VS Coelho (2007) 'Spaces for change? The politics of participation in new democratic arenas', in A Cornwall and VS Coelho (eds) Spaces for Change? Participation, inclusion and voice. London: Zed Books.

Cox, R (1987) Production, Power and World Order, Social Forces and the Making of History. New York: Columbia

Crush, J (ed) (1995) Power of Development. London: Routledge

Declaration of African Ministers Responsible for Water Resources (2001) Bonn International Conference on Freshwater, Bonn, Germany, December 3-7.

Du Plessis, A (2000) 'Charting the course of the water discourse through the fog of international relations theory’, Africa Dialogue, Monograph Series No 2. Pretoria: African Water Issues Research Unit, University of Pretoria

Epstein, S (1996) Impure Science: Aids, activism and the politics of knowledge. Berkeley: University of California Press.

Escobar, A (1995) Encountering Development: the making and unmaking of the Third World. Princeton, NJ: Princeton University Press.

Homer-Dixon, TF (1996) 'Environmental scarcity, mass violence and the limits to ingenuity', Current History 95.

Ibarra, P (ed) (2003) Social Movements and Democracy. New York: PalgraveMacmillan.

McDonald, D (2000) 'Municipal bureaucrats and environmental policy in Cape Town', MSP Background Research Series, Johannesburg: Graduate School of Public and Development Management, University of the Witwatersrand.

Mehta, L and Z Ntshona (2004) 'Dancing to two tunes? Rights and market-based approaches in South Africa's water domain'. Sustainable Livelihoods in Southern Africa, Research Report No 17, PLAAS, Cape Town: University of the Western Cape.

Mehta, L (2005) 'Citizenship and the right to water: lessons from South Africa's 
free basic water policy', in N Kabeer (ed), Inclusive Citizenship: meanings and expressions. London: Zed Books.

Mehta, L (2006) 'Do human rights make a difference to poor and vulnerable people? Accountability for the right to water in South Africa', in P Newell and J Wheeler (eds) Rights, Resources and the Politics of Accountability, London: Zed Books.

Murphy, CN (ed) (2002) Egalitarian Politics in the Age of Globalisation. London: Palgrave.

O’Brien, R, AM Goetz, JA Scholte and M Williams (2000) Contesting Global Governance: multilateral economic institutions and global social movements. Cambridge: Cambridge University Press.

Ohlsson, L (1999) Environment, Security and Conflict: a study of Malthusian concerns. Department of Peace and Development Research, University of Goteborg.

PLAAS (2002) Chronic Poverty Report. Cape Town: University of the Western Cape.

Stavenhagen, R (1997) 'People's movements, the anti-systemic challenge', in RW Cox (ed) The New Realism: perspectives on multilateralism and world order. Tokyo: United Nations University Press.

Stienstra, D (1999) 'Of roots, leaves and trees: gender, social movements and global governance', in MK Meyer and E Prugl (eds) Gender Politics in Global Governance. Boston: Rowman and Littlefield.

Swatuk, L (2000) 'The new water architecture in southern Africa: reflections on current trends'. Paper presented to the 'International Workshop “Gold for/of the Future" Sustainable Water Management in southern Africa and Germany and the role of the Private Sector', organised by Coordination South Africa, Bonn, May 3-5.

Swatuk, L and P Vale (2000) 'Swimming upstream: water and discourses of security', CSAS Water and Ecology Series, Working Paper No 3, CSAS: University of the Western Cape.

Tilly, C (2003) 'When do (and don't) social movements promote democratisation?', in P Ibarra (ed) Social Movements and Democracy. New York: PalgraveMacmillan.

Thompson, L (2002) 'Discourses everywhere and not a drop to drink: water as a lens on environmental security', in TA Benjaminson, C Cousins and L Thompson (eds) Contested Resources: challenges to the governance of natural resources in southern Africa. PLAAS: University of the Western Cape.

Turton, A (2000) 'Water wars in southern Africa: challenging conventional wisdom', Africa Dialogue, Monograph Series No 2, Pretoria: African Water Issues Research Unit, University of Pretoria.

World Commission on Dams (2000) Dams and Development: a new framework for 
decision-making: report of the World Commission on Dams. London: Earthscan. Wynne, B (1996) 'May the sheep safely graze? A reflexive view of the expert-lay knowledge divide', in S Lash, B Szerszynski and B Wynne (eds) Risk, Environment and Modernity: towards a new ecology. London: Sage.

\section{Skuifraam/BWP Documentation}

Argus Environmental Reporter (2005) Environmentalists to Blame for Water Crisis, January 6.

CCT, Bulk Water Supply Division (2004) Draft Water Resource Planning/Tariffing Approach to the BWP/Impact of the BWP on the Average Water Tariff, June.

City of Cape Town (2001) Water Services Development Plan (WSDP).

The Department of Environment and Tourism (2005) Report on Environmental Monitoring Committees.

The Environmental Monitoring Group (2001) Annual Report. Cape Town: EMG. Van Niekerk, P and M Luger (2001) 'Experiences in applying the World Commission on Dams Guidelines to the proposed Skuifraam Dam'. Paper presented at the SANCOLD Symposium on the World Commission on Dams report, held in Midrand, July 23-24.

DWAF (2001) Letter from Minister Ronnie Kasrils to the EMG, May 8.

Environmental Monitoring Committee (2004) Author's Verbatim Transcript of Public Meeting, June 10, 2004.

Environmental Monitoring Committee (1999) Official Letter in response to Skuifraam Dam Initiative, addressed to the Department of Environment and Tourism (DEAT) and the Department of Water Affairs and Forestry (DWAF), July 29.

Muller, M (2001) Official Address to WCD Multi-Stakeholder Symposium, DWAF.

Ninham Shand (1996) Skuifraam Feasibility Study, Vols One and Two, October.

Ninham Shand Feasibility Study Documentation (1996) The Environmental Impact Assessment and Responses from Interested and Affected Parties.

South African Municipal Workers Union (SAMWU) (1999) Press Statement, July29.

The Department of Environment and Tourism (2005) Report on Environmental Monitoring Committees.

The Environmental Monitoring Group (2001) Annual Report, Cape Town: EMG. Van Niekerk, P and M Luger (2001) 'Experiences in applying the World Commission on Dams Guidelines to the proposed Skuifraam Dam'. Paper presented at the SANCOLD Symposium on the World Commission on Dams report, held in Midrand, July 23-24. 
Water/Amanzi (1995) Plain Language Information Pamphlet on the Skuifraam Dam, Ninham Shand, Zille Shandler Associates and Rudevco.

Western Cape Systems Analysis, Ninham Shand and DWAF (1997) Evaluation of the Options Review of the Process, November.

\section{Interviews}

Dowling, P, Wildlife and Environment Society of Southern Africa (WESSA), Western Cape Branch, June 8, 2004.

EMC Meeting, Informal communication with David Venter (Chair) and Martie Van Rensberg; verbatim transcription of proceedings June 10, 2004.

Fourie, M, Berg River Downstream User Group Committee, Follow-up Interview June 5, 2004.

Fourie, M, Berg River Downstream User Group Committee, Interviews December 12, 2003.

Gorgens, Dr A, Chief Engineer on BWP, Ninham Shand, June 1, 2004.

Greeff, L, Coordinator, Water Justice Programme, Environmental Monitoring Committee, July 16, 2004.

Killick, M, Engineer, Bulk Water Supply Division, Cape Town Metropolitan Council, follow up interview June 15, 2004.

Luger, M, Engineer and author of the Skuifraam Dam EIA, Ninham Shand, May 18, 2004.

McDaid, L, Interview July 14, 2004.

Mostert, Heinrich, Convener, Reticulation Services, Cape Town Metropolitan Council, May 11, 2004.

Shandler, D, Director, Ziller Shandler and Associates, now renamed Common Ground, Interview June 17, 2004.

Van Zyl, B, Catchment Manager, DWAF, Interview May 2, 2004.

Venter, D, Chair of the Environmental Monitoring Committee, Interview 8 May, 2004; Interview May 22, 2005; Interview August 17, 2006.

\section{Acronyms}

$\begin{array}{ll}\text { ARN } & \text { African Rivers Network } \\ \text { BWP } & \text { Berg Water Project } \\ \text { CBOs } & \text { Community-Based Organisations } \\ \text { CCT } & \text { City of Cape Town } \\ \text { CMC } & \text { Cape Metropolitan Council } \\ \text { CMA } & \text { Cape Metropolitan Area } \\ \text { CMA } & \text { Catchment Management Agencies }\end{array}$




\begin{tabular}{|c|c|}
\hline CPR & Chronic Poverty Report \\
\hline $\mathrm{CSO}$ & Community Based Organisations \\
\hline DA & Democratic Alliance \\
\hline DEAT & Department of Environment and Tourism \\
\hline DWAF & Department of Water Affairs \\
\hline EIA & Environmental Impact Assessment \\
\hline EMG & Environmental Monitoring Group \\
\hline EMC & Environmental Management (now Monitoring) Committee \\
\hline FBW & Free Basic Water \\
\hline GSMs & Global Social Movements \\
\hline IDP & Integrated Development Plan \\
\hline IUCN & World Conservation Union \\
\hline IWRP & Integrated Water Resources Plan \\
\hline NAWISA & Network for the Advocacy of Water Issues in Southern Africa \\
\hline NEPAD & New Partnership for African Development \\
\hline NGOs & Non-Governmental Organisations \\
\hline NP & National Party \\
\hline NRM & Natural Resource Management \\
\hline NSMs & New Social Movements \\
\hline NWA & National Water Act \\
\hline PLAAS & Programme for Land and Agrarian Studies \\
\hline ROD & Record of Decision \\
\hline SADC & Southern African Development Community \\
\hline SAMWU & South African Municipal Workers Union \\
\hline SANGOCO & the South African NGO coalition \\
\hline SAWC & South African Water Caucus \\
\hline SIRWA & structurally induced relative water abundance \\
\hline SMs & Social Movements \\
\hline TCTA & TransCaledon Transport Authority \\
\hline WCD & World Commission on Dams \\
\hline WCSA & Western Cape Systems Analysis \\
\hline WCUG & West Coast User Group \\
\hline WDM & Water Demand Management \\
\hline WEJP & Water and Environmental Justice Programme \\
\hline WESSA & Wildlife and Environmental Society of Southern Africa \\
\hline WSA & Water Services Act \\
\hline WSDP & Water Services Development Plan \\
\hline WSSD & World Summit on Sustainable Development \\
\hline
\end{tabular}

